\title{
“NARRATIVE OF THE SELF “: THE DISCOURSE OF DAILY LIFE IN THE ESSAYS BY PARTICIPANTS OF LITERACY WORKSHOP
}

\author{
Mundi Rahayu, Deny Efita Nur Rakhmawati
}

\author{
mundi@bsi.uin-malang.ac.id \\ denyefita.nr@bsi.uin-malang.ac.id \\ UIN Maulana Malik Ibrahim Malang \\ Malang, East Java, Indonesia
}

\begin{abstract}
Literacy workshop is important activity delivered in community to increase people's competencies not only in reading and writing, but more importantly in building critical perspectives. However, the result of the literacy workshop needs to be examined, not only to find out the success indicator of the workshop, but also to understand the narration presented in young peoples' works. It is necessary to get the idea of what the young people's concern and thought. This paper discusses the writings as the products of literacy workshop held at Trenggalek, East Java, which was attended by young people as participants. The workshop results in 12 writings, consisting of two short stories, and 10 essays. The questions raised in this paper are; how is the discourse of daily life represented in the writings of the literacy workshop participants? What are the social and cultural factors affecting the writers in constructing the discourse? This paper argues that young people's concern reflects the current social cultural issues that matters in our life. Literacy for young people is not merely giving the skill of reading and writing, but it is a meaning-making process, that enable them to construct the meaning of their everyday life.
\end{abstract}

Keywords: rural literacy, young people, empowerment, daily life

\section{INTRODUCTION}

The literacy movement is one of priorities in the Indonesian education, so that there are strategies of developing literacy launched by Indonesian ministry of education and it is derived into many actions at the formal and informal educational institution (Kemendikbud RI, 2015). Workshop on literacy that improves the competencies of writing has been carried out by many literacy groups or communities. Unfortunately, there is lack of research on the result of the workshop. Therefore, it is important to study the result of the literacy workshop that has been carried out at Trenggalek regency, to figure out young people's aspiration and concerns on social cultural issues (Storey, 1993).

Literacy has important roles not only for the people here and now, but more importantly, in the future life of young generation. As stated by Muhadjir Effendy, Indonesian minister of education (Kemendikbud RI, 2015), in order to be competitive at international level, it is important to build literacy. A nation with high literacy shows that it is able to collaborate, be critical thinking, creative, and communicative to win in highly competitive global sphere (Kemendikbud RI, 2015). Literacy in the forms of narrative is the culturally most potent formal expression of human engagement with the world through speech or writing (Kress, 2003). In its development, the study of literacy evolves as Godzich perceives there is an epochal shift in concepts and practices of literacy not only in regards to writing programs but in the struggles over theory and the challenge offered by emergent literatures. There are raising new questions about the literary and critical presuppositions within 
which all university scholars function (Godizch, 1994).

The present article is aimed at contributing to the study on literacy in Indonesian context which mostly tend to put the literacy under the discourse of developing reading skill (Hasanah,2018). This study applies critical discourse analysis to get understanding on the articles written by the participants after they attend literacy workshop. Accordingly, the research questions are formulated as follows; (a) How is the discourse of daily life represented in the writings of the literacy workshop participants? (b) What are the factors affecting the writers in constructing the discourse?

In this paper, the writers argue that literacy workshop functions not only to equip participants for the ability of reading and writing. The most important function of literacy is the meaning-making process (Pahl \& Escott, 2015). Through this meaning making process, participants or students do not only practice of how to write, but more importantly, they practice of constructing the meaning of their everyday life. As a meaning-making process it implies that literacy activities are always put in the socio-cultural context (Pahl \& Escott, 2015; Rowsell \& Pahl, 2015). Literacy also functions as a means of empowerment, meaning that the writers empower themselves to build critical perspectives in producing texts (Kral \& Schwab, 2012).

\section{New Literacy Paradigm}

Literacy is important issue world wide. The discourse of literacy got its higher importance, mainly when it became the agenda at an international body. World Economic Forum, an institution that has power to drive the future of human well-being, has formulated literacy in its WEF Conference (WEF (World Economic Forum), 2015). One of the important marker in literacy decelopment is the use of digital technology. Digital communication has transformed literacy practices world wide (Mills, 2010). So, the WEF concluded that there are six foundational literacies that the generation of industrial revolution 4.0 has to manage. They are basic literacy; numeric literacy, science literacy, digital literacy, financial literacy and cultural and civic literacy (WEF, 2015).
Literacy has been an important agenda of many countries in modern times, so that the study of literacy developed. The existed dominant view on the concept of literacy is the cognitivist perspective, which sees literacy as a set of technical skills possessed, like reading and writing (Bloome \& Greene, 2015). However the development of studies in education anthropology, linguistic anthropology and sociolinguistics have highlighted the importance of literacy as studies of the social and cultural behaviour associated with literacy (Rowsell \& Pahl, 2015). Through these studies, the paradigm of literacy has shifted from a traditional, cognitivist view of literacy towards the new paradigm of literacy, which engages with literacy as a situated social practice inextricably embedded within time, place, and culture (Kosnik, et al. 2016).

The new paradigm of literacy applies social and cultural behaviour associated with literacy. The study done by Toni Gennrich shows that teachers who are teaching literacy can change deeply entrenched ways of thinking about and valuing literacy by reflecting on the discontinuities between old and new ways of practice and, through anticipatory reflection, to imagine possibilities of teaching and enacting literacy differently (Gennrich, 2016). A fundamental tenet of anthropology shows that cultural forms are transmitted from one generation to the next through socialisation, as well as direct and indirect teaching and learning (Rowsell \& Pahl, 2015).

In the new perspective of literacy, we can find out that literacy is not merely a skill to read and write, instead it is sociocultural perspective. Many researchers have done studies on writing development and how to facilitate it effectively (Jenkins \& Earle, 2006). However, the most comprehensive voice on this literacy study not only examine the writing skill because reading and writing can only be understood in the contexts of social, cultural, political, economic, and historical practices to which they are integral, of which they are a part" (Kosnik et al., 2016) . This sociocultural approach to literacy is called as New Literacy Studies.

The new paradigm of literacy has been strongly influenced by anthropologists Brian Street and Shirley Brice Heath and their ethnographic approaches to language and 
literacy research (Heath 1983; Heath and Street 2008; Street 1995). Street and Heath suggest that an ethnographic approach requires researchers to take young people and their cultural practices seriously by looking at what is happening, rather than what is not happening (Kral \& Schwab, 2012). Ethnographic studies of literacy stand at the interface between anthropology and sociolinguistics and look at the social practices, social meanings, and the cultural conceptions of reading and writing (Kral \& Schwab, 2012). The paradigm is going to cover the present study of literacy.

In understanding the writings resulted from a literacy workshop, the material culture approach to literacy is approriate to be applied, with a particular focus on writing. In this case, language and literacy practices intersect with the material world. The material culture perspective gives the lens as a heuristic for understanding the flow of meaning making that lead to insights about how communicative practices are constructed and emerge from everyday settings. In other word, the cultural materialist approach is an approach for meaning-making practices, by seeing culture unravelled in material objects to combine with writing, speech and other modes (Pahl \& Escott, 2015).

\section{METHOD}

This paper discusses the discourse of young people's daily life, especially those living at Trenggalek through the 12 articles consisting of 2 short stories and 10 essays. The writers are the participants of literacy workshop held on June 2019. The written articles are published online in July 2019 at the portal "nggalek.co"- a local portal based in Trenggalek. In addressing the discourse of daily life represented in the articles, the researcher posts two questions, mainly how is the discourse of daily life represented in the articles which are included under four themes. Second question, what are the factors affecting the writers in constructing the discourse of daily life.

To answer the questions, this paper applies Fairclough's critical discourse analysis (Fairclough, 1989). The Critical Discourse Analysis (CDA) proposes the analysis of a textual discourse by comparing, interpreting, and synthesizing data ((Fairclough, 1989;
vanDijk, 2008). Fairclough's CDA is based on three levels of analysis, in which the first level covers the micro level, with the analysis related to language phenomenon such as wording, metaphor, and syntax. Second, meso level, in which the analysis is related to the production and consumption of the text. At macro level, the analysis examines socio-political context of the text. In discussing the twelve articles published in portal "nggalek.co" on July 2019, the writer will focus upon the discourse of daily life, the way it is constructed as well as the relationship among individuals and society in this issue.

\section{DISCUSSION \\ The Discourse of Daily Life}

The discourse of daily life explores how people think, write and discuss about their lives, their individual and surroundings issues. The discourse as found out in this paper supports the idea of new paradigm of literacy in which it emphasizes the sociocultural perspective. The discussion in this study is also in accordance to the material culture approach in which the language and literacy practices intersect with the material world. What the writers express in the writings are based on their elaboration and contemplation on the real issues they encounter in the daily life.

Under the concept of Fairclough's CDA, the findings of this study show that the issues the writers have expressed in the writings are closely related to their socio-political context. Through the writings, the young people express their social criticism. In some cases they also represent negotiation between the local government and people as the beneficiearies of the project.

These daily issues are represented in 12 articles, which are written by the participants of literacy workshop, most of whom are young people (students of Aliyah, and two are fresh graduate) living in Trenggalek. The students of Aliyah (Islamic senior high school) do not have a literacy as a specific subject in their school. So, for most of them, this literacy workshop is the first time they have ever had. In the workshop, the participants get the knowledge and skill of how to write for online publishing like blog or local portal. They are free to choose a topic to write, and guided by some senior writers to finally publish their article in the local portal, nggalek.co. 
It can be seen that the 12 articles are resulted from the observation and experience of the writers' life and concerns. These articles are written under four themes as can be seen in the following table.

Table 1. The themes of the writings

\begin{tabular}{|c|c|c|c|c|}
\hline No & Themes & $\begin{array}{l}\text { Number } \\
\text { of } \\
\text { articles }\end{array}$ & $\begin{array}{l}\text { Titles of the } \\
\text { articles }\end{array}$ & Genre \\
\hline \multirow[t]{3}{*}{1} & \multirow[t]{3}{*}{$\begin{array}{l}\text { Motivating } \\
\text { young } \\
\text { people for } \\
\text { future life }\end{array}$} & \multirow[t]{3}{*}{3} & $\begin{array}{l}\text { (1) Tantangan } \\
\text { Generasi } \\
\text { Milenial (The } \\
\text { challenge for } \\
\text { millenial } \\
\text { generation) }\end{array}$ & Essay \\
\hline & & & $\begin{array}{l}\text { (2) } \\
\text { Berorganisasi } \\
\text { untuk Masa } \\
\text { Depan (Being } \\
\text { in organization } \\
\text { for the future) }\end{array}$ & Essay \\
\hline & & & $\begin{array}{l}\text { (3) Kisah Haru } \\
\text { Pemudi Tugu } \\
\text { (Melancholic } \\
\text { Story of a girl } \\
\text { from Tugu) }\end{array}$ & $\begin{array}{r}\text { Essay } \\
\mathrm{S}\end{array}$ \\
\hline \multirow[t]{3}{*}{2} & \multirow[t]{3}{*}{$\begin{array}{l}\text { Pesantren } \\
\text { life }\end{array}$} & \multirow[t]{3}{*}{3} & $\begin{array}{lr}\text { (4) Ramadan } \\
\text { Pertama } & \text { di } \\
\text { Pondok } & \text { (First } \\
\text { Ramadan } & \text { at } \\
\text { Pondok) } & \\
\end{array}$ & Essa \\
\hline & & & $\begin{array}{l}\text { (5) Pamitan } \\
\text { (Farewell) }\end{array}$ & Stor \\
\hline & & & (6) Kang Ceples & Story \\
\hline \multirow[t]{2}{*}{3} & \multirow[t]{2}{*}{$\begin{array}{l}\text { People's } \\
\text { behavior and } \\
\text { Environment } \\
\text { issues }\end{array}$} & \multirow[t]{2}{*}{2} & $\begin{array}{l}\text { (7) Memerangi } \\
\text { Karbondioksida } \\
\text { dengan } \\
\text { Merawat Pohon } \\
\text { dan Bersepeda } \\
\text { Ontel (Fighting } \\
\text { against } \\
\text { carbondiocide } \\
\text { through } \\
\text { planting a tree } \\
\text { and bicycling) }\end{array}$ & Essa \\
\hline & & & $\begin{array}{l}\text { (8) Trenggalek } \\
\text { Saat Musim } \\
\text { Bediding } \\
\text { (Trenggalek at } \\
\text { the fall) }\end{array}$ & $\begin{array}{r}\text { Essay } \\
i\end{array}$ \\
\hline 4 & $\begin{array}{l}\text { Social } \\
\text { economic } \\
\text { issues }\end{array}$ & 4 & $\begin{array}{l}\text { (9) Warga } \\
\text { Watulimo } \\
\text { Shock Akibat } \\
\text { Harga Cengkih } \\
\text { Anjlok (People } \\
\text { at Watulimo are }\end{array}$ & \\
\hline
\end{tabular}

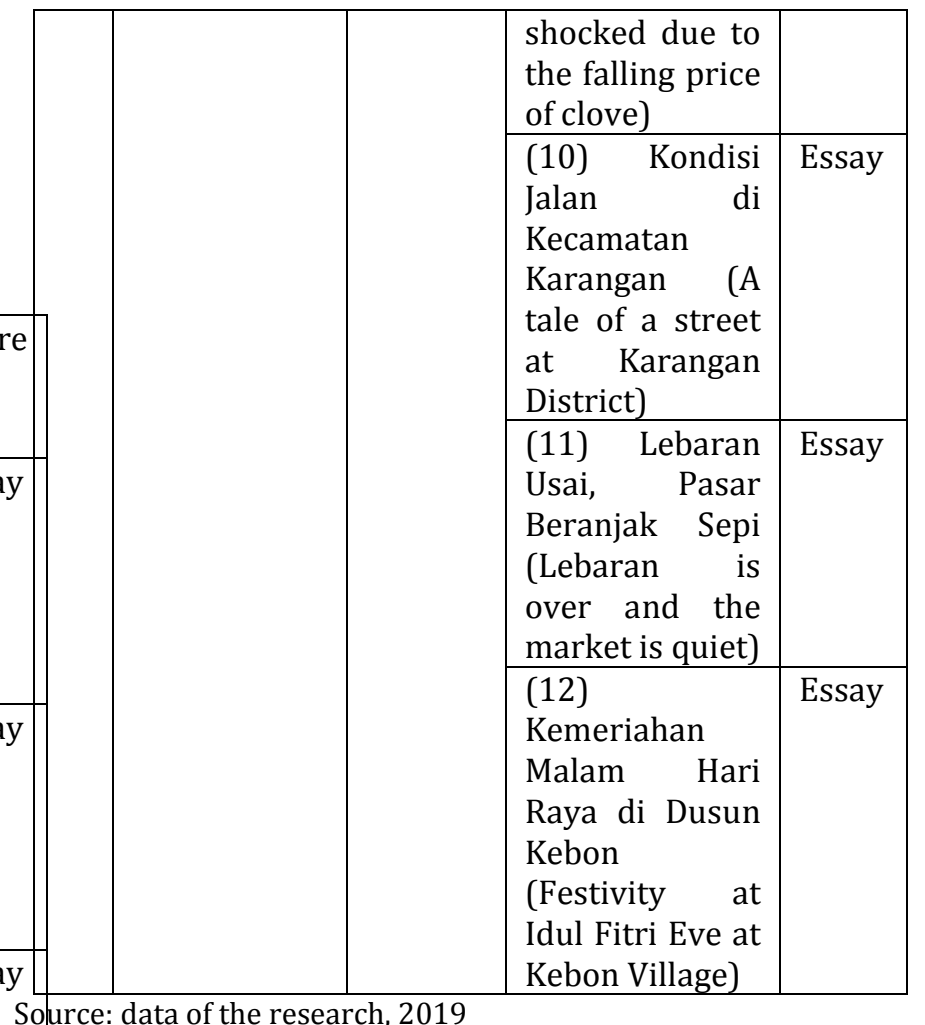

Source: data of the research, 2019

As it can be seen at the table above, the discourse of daily life is represented under four (4) Ramadan Essaythemes of the articles. The first theme, "Motivating young people for future life" is one of important themes for the young people's life, as the young people need to motivate their peer groups to catch their dream. There are three articles under this theme; Tantangan Generasi Milenial (The challenge for millenial generation), Berorganisasi untuk Masa Depan (Being active in organization for the Future), and Kisah Haru Pemudi Tugu (Melancholic story of a girl from Tugu).

The first article represents the ideas that the most challenging matter for young millenial generation is the technology development, and globalization, including internet things. Beside the benefit of technological development for human being, this article also identifies three atechnogical bad impacts for young people; instant culture, fake news and cyber crime. The writer's concern on the these impacts is driven by the social facts that the writer observes in daily life, especially in the interaction with internet things. So, these are among biggest challenges to overcome for young people.

Globalization in young people's eyes is closely related to the advancement of information technology and internet things. Lexically, globalization is derived from the 
word "global", the world, which means that any places in the world are connection each other because of trade and technology. Although they live in rural areas, the writers are able to feel and see the world through the internet. They feel connected with the world. The internet makes them realize the many abundant international information and at the same time they realize some bad impacts that need to be aware of.

The article number two (2) represents the ideas that being active in organization is important and beneficial for young people, as he makes himself as example. By being active in organization he is able to be confident in speaking in front of public, teach him to be loyal and dedicated to the organization, and develop the spirit to help other members. The writer intends to motivate other young people to do the same thing. He is worried that many young people do not keen on being active in organization because they think it is unnecessary. Moreover, there is increasing trend of 'instant culture' among young people.

The article number 3 represents the case of how a young girl realized the real life. Her difficult situation makes her think hard what she should do to reach her dream. This writing says that nothing is easy, a dream needs extra effort to be come true. This idea is based on the writer's observation, that there are many young people who take instant ways to reach the goal, not considering the long process that $\mathrm{s} /$ he has to take. The article represents the ideas that those who do not want to work hard will fail.

From the first theme articles, it can be seen that young people's daily life can not be separated from the technological development. We can find out that information technology and internet things reach out to the rural areas with no exception. The competency on the information technology is crucial in daily life, and this is challenging for young people considering the bad impacts of the technology. Meeting the challenge can be done through mastering the (information) technology, and practice in organization which will equip young people with communication skill and building perspective in facing many problems.

These three article shares one important thing, that the young people need to work hard, struggle for their future, because the future is complicated and challenging. To some people, the technology development makes people dependent on technology and tend to be pragmatist. As it is mentioned in the articles, the "instant culture" leads people to choose anything that is fast, instant, without more time and energy to do or to get something. On the other hand, to survive and able to develop, people need to build competencies in internet things, in managing the time and problems.

The first theme, motivating young people to struggle for their future, is important matter for the writers' own interests. It reflects the ideas on how young generation have to face millenial challenge in the digital era, and be critical with instant culture. The theme implies that for many young people, they are worried and need to have advices or inspiration and perspectives as well as hacks to be able to survive and develop their utmost potencies. Their concern on this situation reflects the condition of young people at large, the necessity to master technology and at the same time be aware of the bad sides of the technologies.

The second theme is pesantren life with three writings, one essay and two short stories. The article "Ramadan Pertama di Pondok" (First Ramadan at Pondok) represents the writer's experience as a new santri (student at Islamic boarding school). As a santri, she narrates simple things of daily life in Ramadan month in pesantren. Ramadhan is considered as a special month for Muslim because they have to fast in the whole month and this is special because in the month, those who do many good deeds will get multitude reward from Allah. The life in the pesantren is presented as the one that most of the students want to have, because of many friends in learning activities at the pesantren (Islamic boarding school). Much more than conventional school, activities in pesantren are scheduled from very early morning, before Subuh till after Isya (dusk to dawn). But they do it in more relax situation, not as formal as in the classroom. As a student at pesantren, the author writes the experience in a very happy and positive tone, and she presents them all as important things for her life.

The article number 5 is a short story under title "Pamitan" (Farewell) which tells us a story of a santri at home, who is preparing many things to go to pesantren. He does not express any problem related with his living in 
the pondok pesantren. Instead, he is very happy to do anything to bring to pondok pesantren. This might be supported by the fact stated in the story, that his father is rich enough, which can be proven by the father drives a car to bring him to pondok pesantren. So, for the writer, going to pesantren is a nice place, and he is looking forward to be there, ready with the activities. As an educational institution, pesantren is represented as a simple, affordable school that teaches the students simple way of life.

The article number 6, entitled "Kang Ceples," is a story about a santri, who is very lazy. Most students of pesantren are diligent enough to attend many activities in the pesantren. The ustadz (teachers) in the pesantren are successfully making the students obey any rules. However, there is always an exception. This story narrates a boy who is called "Kang Ceples," who is lazy to attend the Subuh prayer. This boy is interesting to be told to show how lazy boy is treated in pesantren system. The rule is, if there is any student who does not attend the Subuh prayer together (in jamaah), he will be punished, because it means he violates the rules. However in the case of Kang Ceples, the punishment is not a harmful one, instead it is something funny and easy to do. The other students are just as happy as kang Ceples in doing the 'punishment.'

The second theme, pesantren life, represents the daily life of santri at the pesantren, which is a kind of traditional Muslim boarding school. The pesantren that they attend is a kind of traditional one, not the modern one. As a traditional pesantren at surrounding Trenggalek, commonly the school fee is affordable for all of the santri. This kind of dormitory is the modest but enough for the simple daily lifestyle. They eat two or three times a day with a very simple, ordinary meal. The place is not a very big building like the modern pesantren, instead, it is a complex of simple housing. It is seen from the narration that the pesantren is a traditional school that enables students (santri) to learn and practice many things from the daily activities up to reading and discussing the sacred religious books. Pesantren is the place for building santri's basic competence in religious studies and in life.

The third theme is "People's behavior and Environment issues" with two articles,
"Memerangi Karbondioksida dengan Merawat Pohon dan Bersepeda Ontel (7)" (Fighting against Carbondioxide through planting and nurturing trees and riding bicycle) and "Trenggalek Saat Musim Bediding (8)" (Trenggalek in The Autumn). The article number seven narrates the environmental issues and people's behavior related to the issue. The writer proposes that the awareness to the environmental issue should be built by everybody. The essay proposes, what if every body has a kind of lisence, like driving lisence, showing that he or she is responsible for, at least, the life a tree. The writer also proposes anybody to use bicycle instead of motorcycle or car that produces emission of carbondioxide. The writer calculates the emission of the motorcycle and motorcar every minute, hour, day, and month. The calculation shows that the gas emission from the motor with the petroleum fossil-fuel is terrible and harmful for human being.

"Trenggalek at the autumn" represents the situation of Trenggalek area at the autumn which happens around June-August. In this time, the temperature is low, and people, especially those living in mountainous areas, usually did not take a bath early in the morning because of the cold. Moreover, there are less water supply at their wells and river in the season. In agricultural community, people's activities are influenced by the natural condition. In such cold temperature, people like to flock at warm places, at around the traditional stove (hearth) at the kitchen. This area is the warmest place at home, in literal sense.

The environmental discourse is discussed in a simple way, embedded in the daily life, in which the writer proposes something considered ideal but it actually can be practiced in daily life. The responsibility of "caring one tree" is not a big problem for agricultural community. At Tranggalek area, people are agriculturalist sothat it is very common for them having trees, not only one or two. They have dry field that most of them plant many trees (fruit trees, or main crops trees). Naturally people at Trenggalek are still close to nature. However this idea will find problem when it is applied to urban areas. The essay that highlights environmental issue also means that the concern is urgent and close to our daily life. 
The fourth theme is social economic issues with four articles. The first article is "Warga Watulimo Shock Akibat Harga Cengkih Anjlok" (Watulimo people was shocked because of the falling price of cloves.) This article represents most of Watulimo people's concern on the price of clove at the harvesting time lately. The contrast situation is presented here, in which the harvesting time is when most of people at Watulimo are busy with harvesting the clove, and their surrounding houses full of cloves to be dried. As commonly happen, harvesting time is a happy time. Cloves used to be a very valuable commodities. But it is not anymore. The price of dry clove is sharply declining, so that clove farmers, majority farmers in this area, feel frustrated with this situation, and the government is not able to do anything to overcome this situation.

The paper entitled "Kondisi Jalan di Kecamatan Karangan" (The condition of a Street at Karangan District) narrates the story of a street at Karangan district, in which it was very bad condition and after a long time, the government repaired it and made it better. After the street was renovated into a better condition, it brought economic impact for the people living along the street. Many stores and stalls open along the street. However, without a good management it brings about some bad impact such as waste and the lack of parking lot as an imporant facilities for the consumers.

In discussing the project of street renovation, it is commonly understood by people anywhere that renovation project commonly becomes political project by local government (village or district administration). This will be done with the government's interest. For example, if the local parties/candidate won the election he would renovate the street. In addition, if the local government do not have any interest in renovating the street, it will be let stranded in bad, bumpy road for a long time. From this discussion on the topic of a street at Karangan district, it can be said that the article represents the discourse on the street in critical perspectives, that is the problems of waste and parking lots. The discourse of a street belongs to daily life issues, because many people have interests in this issue.

The article entitled "Lebaran Usai, Pasar Beranjak Sepi," represents the worried people on economic condition at the grassroot level, when local market had less visitors after Idul Fitri. The sellers in the market complain of less and less buyers. People's low demand is affected by the decline of local commodities prices. This issue is related to the previous article on the falling price of cloves. All of this condition reflects the real situation of the people in the aftermath of Idul Fitri. The issue of falling price of clove and other local commodities and crops is represented and discussed in many levels and arena, including this article. The discourse of the economic issue is represented as the real daily life issue that circulates at grassroot level (local market, farmers, local people).

The article entitle "Kemeriahan Malam Hari Raya di Dusun Kebon" represent how people celebrate Idul Fitri Eve at Kebon Hamlet, which is done through three things, "firecracker, fireworks and air balloon". Albeit a pledge from the local police for not to fire firecracker and air balloon, because of its danger in which the candle in the baloon can burn the dry bushes, people do not obey. They think that this tradition has been done for generations especially in this village. People from other village coming to this Dusun Kebon only for enjoying this celebration, so they are proud to do this eventough the police forbid them. The people at the hamlet is serious in managing the 'show' of fireworks and air balloon so that they are willing to spend their own money for buying all these fireworks and air balloon.

The first and second themes construct the narrative of the young people's self. They construct the discourse of motivating young people to work hard. Those who are living in this digital, globalized era, both males and females have to work hard for their success in their future. The development of technologies helps people to do anything in easier and more practical ways. However, there is technological trap that makes young people lazy, do not work hard, and doing anything in more instant ways. The spirit to work hard is important for people's survival and development.

The third and fourth themes construct the discourse of the interconnectedness between social economic and environmental problems. These issues always bring real problems for people at the grassroot, who depend their lives on the market, on the cloves harvest and other crops. When the price of the 
crops decline, the people's buying power is weak, and frustration will surge. The writings lead to the discourse that people can not depend their well being on government. Government can not do anything to face the decline of cloves price. The improvement of transportation facilities, streets, can only be done after many decades. Nevertheless, the street improvement was not done in comprehensive ways, by considering the critical perspective narrated in the story of a street at Karangan district. Besides, environmental problems do not become a priority for local government. It seems that the environmental issue is only marketable at the international level. At the local government level, those who have concern on the environmental issue is only dare to say "what if".

\section{The Factors Contributing to the Constructed Discourse of Daily Life}

As mentioned above, there are four themes emerging from the articles. The four themes are: Motivating young people for future life, Pesantren life, People's behavior and Environment issues, and Social economic issues. The themes construct the discourse of young people's concern on their life and social economic issues in rural areas of Trenggalek. At least there are three factors affecting the construction of the narration of young people's life; educational, social and cultural factors

Educationally, there are two groups of young people in this workshop. The first group is the students of senior highschool level, and the second group is the university students. The educational background affects the topic choice for writing. For the highschool students, it is important for them to address the issues like leadership training in organization, the challenges for millenial generation, living in Pesantren, all of which motivate the students to face the challenges in this changing world. The social cultural context of technological development affect them in constructing the discourse.

For those who have been in the tertier level of education (university or institute), their concerns seem to be wider. They narrate much on social and environmental issues in more critical perspectives. The article like the story of a street at Karangan district discusses the historical perspective of a street that is important for the local people's interest. The falling price of cloves harvest that gives big impact for people at large economically and socially, shows the deep concern on their surrounding. Not only do they observe their surrounding, they have their own experiences on this problem and present it in critical perspective.

The educational background also influences the writing competency. Writing skill is a competency that needs to be improved from time to time. Most of the writers has got the workshop on writing skill for the first time. A few of them has got some experience in writing. Those having previous experience of writing have capability to write the essays in better techniques. Writing a good essay needs a more critical perspective to explore the social economic issues. In addition, the references or books they have read also influence their perspectives.

The social factor contributes to the young people's concern on many social issues. The young writers are trained to be a good writer in which at the same time also a good social observer. They are mostly from the families living at the rural areas in Trenggalek. The life at the rural areas is commonly different from the urban one. In this region, people know each other and build social cohesiveness. Their social relations make them familiar with the social problems in their neighborhood and surrounding. Their habitus can be seen from their writing. The topic of social media, internet technology are among other things that challenge them, because the young people as the users are also part of the social relations offline.

The cultural factors are the ones related to the tradition and cultural ethos, that build their daily habits. The writers are young people, students of Aliyah and new undergraduates living in Trenggalek. It is a small town surrounded with agricultural life. The landscape of Trenggalek are combination of coastal area and mountainous area, so most of the people are farming and fishing as their living. The geographical and social life construct the writing which is based on their observation and experience at the agricultural community, and at pondok pesantren where they live in. They live not only with long-rooted tradition, but also the modern and internet technology as users. Through the literacy 
workshop, they are encouraged to master the technology not only as the consumers but also as producers, mainly as content writers.

\section{CONCLUSION}

The study on the 12 writings as the result of literary workshop, which applies critical discourse analysis, shows that the discourse of daily life represented in four themes of the writings. The discourse of young people's daily life is related to motivating young people to work hard. Working hard for young people at rural areas, in this digital, globalized era, is not enough. They need to be equipped with familiarity and knowledge to (information) technology that helps people to accomplish the tasks. However, they need to be aware with the technological trap of instant culture.

The discourse of daily life is also represented in the interconnectedness between social economic and environmental problems. These daily issues are the problems that affect people's lives at large, at the public sphere such as market, street, at neighbourhood. In this case, government's roles are at stake. The writers' critical perspectives on the issues show their serious concern and finding the weakness of the local government.

Three factors affecting the construction of the narration of young people's life; educational, social and cultural factors imply that the social economic issues presented in the writings are discussed under the local context. The educational background of the writers, social and cultural context of the events contribute to the construct of the discourses of daily life among young people.

The concept of literacy and the new paradigm of literacy which applies ethnographical and antropological studies support the study which applies Critical Discouse Analysis. Fairclough's CDA with three levels of analysis, micro, meso and macro answer the problems posted, the discourse analysis of the text, and the factors affecting the constructed discourses. In addition, we also take a cultural materialist approach to meaning-making practices, seeing culture unspooling in material objects to combine with writing. In this way, literacy's effects flow from its social and cultural contexts.

This research is limited to the discussion on the discourse of daily life of the 12 writings written by participants of literacy workshop. There are many other topics that can be discussed further from the writings as the result of literacy workshop, that can be examined through many other theories. So we suggest that the next researcher interested in literacy study is able to examine the text by applying new paradigm of litercy concept which varies from anthropological, ethnographical, and other sociological language studies.

\section{REFERENCES}

Bloome, D., \& Greene, J. (2015). The Social and LinguisticTurns in Studying Language and Literacy. In The Routledge Handbook of Literacy Studies (pp. 19-34). Routledge.

Fairclough, N. (1989). Language and Power. Longman Group UK Ltd.

Gennrich, T. (2016). 'I got content with who I was': Rural teachers' encounters with new ways of practsing literacy. Reading \& Writng - Journal of the Reading Associaton of South Africa, 7(2). https://doi.org/10.4102/rw.v7i2.109

Godizch, W. (1994). The Culture of Literacy. Harvard University Press.

Jenkins, C. B., \& Earle, A. A. (2006). Once upon a fact: Helping children write nonfiction. Teachers College Press.

Kemendikbud RI. (2015). Gerakan Literasi Nasional.

Kosnik, C., White, S., Beck, C., Marshall, B., Goodwin, A. L., \& Murray, J. (2016). Building Bridges; Rethinking Literacy Teacher Education in a Digital Era. Sense. 
Kral, I., \& Schwab, R. G. (2012). Learning spaces: Youth, literacy and new media in remote Indigenous Australia. ANU E-Press.

Kress, G. (2003). Literacy in the New Media Age. Routledge.

Mills, K. A. (2010). A Review of the "Digital Turn" in the New Literacy Studies. Review of Educational Research, 80(2), 246-270. https://doi.org/10.3102/0034654310364401

Pahl, K., \& Escott, H. (2015). Materialising Literacies. In The Routledge Handbook of Literacy Studies. Routledge.

Rowsell, J., \& Pahl, K. (2015). The Routledge Handbook of LIteracy Studies. Routledge.

Storey, J. (1993). The Introduction to Cultural Theories and Popular Culture. Simon \& Schusster International Group.

vanDijk, T. (2008). Discourse and Context; A Socio Cognitive Approach. Oxford University Press.

WEF. (2015). New Vision for Education: Unlocking the Potential of Technology. WEF dan The Boston Consulting Group. 